\title{
Down-regulation of complement genes in lipopolysaccharide- challenged zebrafish (Danio rerio) larvae exposed to Indonesian propolis
}

\author{
Regulação negativa dos genes do complemento em larvas de peixe-zebra (Danio rerio) \\ desafiadas com lipopolissacarídeo expostas à própolis indonésia
}

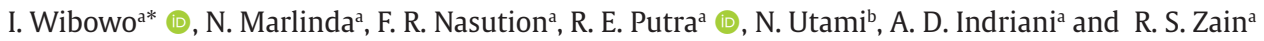 \\ anstitut Teknologi Bandung, School of Life Sciences and Technology, Bandung, Indonesia \\ bIndonesian Institute of Sciences, Research Center for Biotechnology, Cibinong Science Center, Bogor, Indonesia
}

\begin{abstract}
Although propolis has been reported for having anti-inflammatory activities, its effects on complement system has not been much studied. This research was conducted to find out the effects of Indonesian propolis on the expression levels of $C 3, C 1 r / s, B f, M B L$, and $C 6$ in zebrafish larvae which were induced by lipopolysaccharide (LPS). Counting of macrophages migrating to yolk sac and liver histology were carried out. Larvae were divided into four groups: CON (cultured in E3 medium only), LPS (cultured in a medium containing $0.5 \mu \mathrm{g} / \mathrm{L} \mathrm{LPS}$ ), LPSIBU (cultured in a medium containing LPS, and then treated with $100 \mu \mathrm{g} / \mathrm{L}$ ibuprofen for 24 hours), and LPSPRO (cultured in a medium containing LPS, and then immersed in $14,000 \mu \mathrm{g} / \mathrm{L}$ propolis for 24 hours) groups. The results showed that complement gene expression in larvae from the LPSIBU and LPSPRO groups were generally lower than in larvae from the LPS group. The number of macrophage migrations to the yolk in the LPSPRO group was also lower than in the LPS group. Histological structure of liver in all groups were considered normal. This study shows that Indonesian propolis has the potential to be used as an alternative to the substitution of NSAIDs.
\end{abstract}

Keywords: Indonesian propolis, complement system, zebrafish.

\begin{abstract}
Resumo
Embora a própolis tenha sido relatada por ter atividade anti-inflamatória, seus efeitos no sistema complemento, uma parte do sistema imunológico inato, não foram muito estudados. Esta pesquisa foi conduzida para descobrir os efeitos da própolis da Indonésia nos níveis de expressão de C3, C1r/s, Bf, MBL e C6 em larvas de peixe-zebra induzidas por lipopolissacarídeo (LPS). Foram realizadas contagens de macrófagos que migram para o saco vitelino e histologia do fígado. As larvas foram divididas em quatro grupos: CON (cultivadas apenas em meio E3), LPS (cultivadas em meio contendo $0,5 \mu \mathrm{g} / \mathrm{L}$ de LPS), LPSIBU (cultivadas em meio contendo LPS e, em seguida, tratadas com $100 \mu \mathrm{g} / \mathrm{L}$ de ibuprofeno por 24 horas) e LPSPRO (cultivado em meio contendo LPS, e então imerso em própolis $14,000 \mu \mathrm{g} / \mathrm{L}$ por 24 horas). Os resultados mostraram que a expressão do gene do complemento em larvas dos grupos LPSIBU e LPSPRO foi geralmente menor que em larvas do grupo LPS. O número de migrações de macrófagos para a gema no grupo LPSPRO também foi menor que no grupo LPS. A estrutura histológica do fígado em todos os grupos foi considerada normal. Este estudo mostra que a própolis indonésia tem potencial para ser utilizada como alternativa na substituição dos AINEs (anti-inflamatórios não esteroides).
\end{abstract}

Palavras-chave: Própolis Indonésia, sistema complementar, peixe-zebra.

\section{Introduction}

Inflammation is a well-known mark of microbial infections or injuries without any microbial infections (Medzhitov, 2008), characterized by swelling (tumor), redness (rubor), pain (dolor), and increased heat (calor) followed by the loss of function (functio laesa) (Markiewski and Lambris, 2007). However, understanding of the fundamental mechanisms that form the inflammatory response has been increasingly expanded in recent years.
Complement system has been identified as a contributor to various inflammatory pathologies, including pathogen sensing and killing, damaged cell clearance, immune complex handling, and modulation of adaptive immune responses. In general, a controlled inflammatory response is beneficial since it can provide protection against infection. However, inadequate, excessive, or improperly regulated inflammation or complement activation can lead to a

*e-mail: indra@sith.itb.ac.id

Received: January 9, 2021 - Accepted: February 25, 2021 
septic shock (Charchaflieh et al., 2012) that can lead to organ failure (Polat et al., 2017).

Complement is comprising of more than 50 proteins (Thorgersen et al., 2019). It can be activated through classical pathway, lectin pathway, and alternative pathway. These three pathways connect on the formation of $\mathrm{C} 3$ convertases (Markiewski and Lambris, 2007). Complement activation leads to opsonization process followed by phagocytosis, lysis, and inflammation (Dunkelberger and Song, 2010).

The classical pathway is activated when $\mathrm{C} 1$ complex, consisting of $\mathrm{C} 1 \mathrm{q}$ and the proteases $\mathrm{C} 1 \mathrm{r}$ and $\mathrm{C} 1 \mathrm{~s}$, binds to pathogen-binding antibodies (Ricklin and Lambris, 2013). The lectin pathway is activated when mannose-binding lectins (MBL) or ficolins recognize conserved pathogenic carbohydrate motifs, activating the MBL-associated serine proteases (MASPs) (Dunkelberger and Song, 2010). Through activation of $\mathrm{C} 2$ and $\mathrm{C} 4$, both pathways lead to the assembly of $\mathrm{C} 3$ convertase complexes, which cleave the abundant plasma protein C3 into an anaphylatoxin fragment (C3a) and the opsonin C3b (Ricklin and Lambris, 2013). The alternative pathway is activated when $\mathrm{C} 3$ forms the initial C3 convertase through hydrolysis, in the presence of Factor B and Factor D, leading to additional C3 cleavage and formation of the C3 convertase and C5 convertase (Markiewski and Lambris, 2007). Those pathways will result in the formation of the complement system effectors: anaphylatoxins, the membrane attack complex (MAC), and opsonins (Ricklin and Lambris, 2013).

Immune cell migration is also an important mechanism for the inflammatory response. Macrophages are one of the immune cells that react most quickly to pathogens and also have a longer lifespan compared to neutrophils (Galli et al., 2011). The macrophages that are activated due to the presence of pathogens will increase the production of proinflammatory cytokines, such as TNF- $\alpha$, IL- $1 \beta$, and IL-6, so that they can attract other inflammatory cells to migrate to the site of infection and/or inflammation (Kim et al., 2019).

Hepatocytes, the major parenchymal cells in the liver, synthesize $90 \%$ of complement proteins in serum involved in the classical pathway $(\mathrm{C} 1 \mathrm{r} / \mathrm{s}, \mathrm{C} 2$, and $\mathrm{C} 4)$, alternative pathway ( $\mathrm{C} 3$ and Factor $\mathrm{B} / \mathrm{Bf}$ ), lectin pathway (MBL, MASP1-3, and Map19), terminal components (C5, C6, C8, and $\mathrm{C9}$ ), and regulators (factors $\mathrm{I}, \mathrm{H}$, and $\mathrm{C} 1$ inhibitors) (Qin and Gao, 2006). Hepatocytes also have important roles in metabolism and detoxification (Zhou et al., 2016). Although the ability to regenerate is relatively high, after acute injury or resection, this regenerative ability is overwhelmed by two major scenarios: severe acute liver injury or severe chronic liver injury (Forbes and Newsome, 2016). Thus, understanding the mechanism of the liver disease is very important for the development of treatment (Wilkins and Pack, 2013).

NSAIDs (non-steroidal anti-inflammatory drugs) such as ibuprofen, aspirin, and paracetamol are commonly used to alleviate pain, fever, and inflammation. Unfortunately, these anti-inflammatory drugs have negative side-effects if they are used for a long time in high doses. Some serious effects possibly resulting from NSAIDs consumption are the increasing risks of heart attack, stroke, peptic ulcer, bleeding in the digestive system, and kidney disease
(Wehling, 2014). Therefore, it is important to explore new therapeutic methods for inflammation with fewer side effects.

Propolis has been reported to possess some biological activities which are antibacterial, antiviral, antifungal, wound healing, and anti-inflammatory (Oryan et al., 2018). Chemical contents in propolis vary depending on geographic location, plant source, season, and bee species (Huang et al., 2014). The Indonesian propolis used in this study is produced by stingless bees Trigona sp. from Subang, West Java. This research was conducted to find out the effects of Indonesian propolis on the expression levels of $C 3$ (central component), $C 1 r / s$ (classical pathway), $B f$ (alternative pathway), $M B L$ (lectin pathway), and C6 (terminal component) in zebrafish larvae which were induced by lipopolysaccharide (LPS), a major component of the outer membrane of Gram-negative bacteria, that can stimulate innate immune system (Yücel et al., 2017).

\section{Materials and methods}

\subsection{Propolis extraction}

The propolis used in this study originates from Subang, West Java, and is produced by stingless bees Trigona sp. The raw propolis was extracted using ethanol, and its chemical contents were analyzed using GC-MS (Gas Chromatography-Mass Spectrometry).

\subsection{Zebrafish Maintenance}

Zebrafish were maintained in accordance with standard protocol (Westerfield, 2000). Zebrafish embryos and larvae were obtained from natural spawning and kept in Petri dish containing E3 medium ( $5 \mathrm{mM}$ of $\mathrm{NaCl}, 0.17 \mathrm{mM}$ of $\mathrm{KCl}$, $0.33 \mathrm{mM}$ of $\mathrm{CaCl}_{2}, 0.33 \mathrm{mM}$ of $\mathrm{MgSO}_{4}$, without methylene blue) at $26-30^{\circ} \mathrm{C}$ (Nusslein-Volhard and Dahm, 2002).

\subsection{Pigment removal}

Pigment removal was carried out on the larvae whose macrophage migrations would be calculated. Pigment removal was performed by adding $0.2 \mathrm{mM}$ PTU (N-phenylthiourea) to the medium at the end of gastrulation (about 10 hpf) (Karlsson et al., 2001). The medium containing PTU was replaced daily.

\subsection{Treatment of zebrafish larvae}

Treatment of zebrafish larvae was carried out by immersion in 6-well plates. Thirty 5-dpf-larvae per group were placed in well containing $6 \mathrm{~mL}$ of E3 medium. Larvae were divided into four groups: control, negative control (LPS) group, positive control (LPSIBU) group, and LPSPRO group. The control group consisted of larvae which were cultured in E3 medium only. The LPS group comprised of larvae which were cultured in a medium containing $0.5 \mu \mathrm{g} / \mathrm{L}$ LPS (Sigma-Aldrich). The LPSIBU group encompassed larvae which were cultured in a medium containing LPS, and then treated with $100 \mu \mathrm{g} / \mathrm{L}$ ibuprofen for 24 hours by the immersion method (Jones et al., 2012). The LPSPRO group comprised of larvae which were cultured 
in a medium containing LPS, and then given $14,000 \mu \mathrm{g} / \mathrm{L}$ propolis treatment for 24 hours by the immersion method.

\subsection{Quantitative RT-PCR for expression level analysis}

Total RNA was isolated from euthanized larvae (30 larvae per sample) using the PureLink ${ }^{\mathrm{TM}}$ RNA Mini Kit (Thermo Fisher Scientific). The existence of RNAs was analyzed using $2 \%$ agarose gel electrophoresis. The parameters of the RNAs existence were visualized by the presence of $28 \mathrm{~S}(4.8 \mathrm{~kb})$ and $18 \mathrm{~S}$ (2.0 kb) ribosomal RNAs (Aranda et al., 2012).

Before cDNA was synthesized, treatment was carried out using DNAse I (Thermo Fisher Scientific) to remove DNA contamination. A total of $1 \mu \mathrm{g}$ RNA from each sample was mixed with $1 \mu \mathrm{L}$ 10× reaction buffer, $1 \mu \mathrm{L}$ DNAse I, and nuclease-free water, until the final volume was $10 \mu \mathrm{L}$. The mixture was incubated at $37^{\circ} \mathrm{C}$ for 30 minutes and followed by DNAse I inactivation by adding $1 \mu \mathrm{L}$ of $50 \mathrm{mM}$ EDTA. After that, the mixture was incubated at $65^{\circ} \mathrm{C}$ for 10 minutes.

The cDNA synthesis was carried out using SensiFAST ${ }^{\mathrm{TM}}$ cDNA Synthesis Kit (Bioline). A total of $11 \mu \mathrm{L}$ RNA samples which were treated using DNAse I was mixed with $4 \mu \mathrm{L} 5 \times$ buffer first strand, $1 \mu \mathrm{L}$ reverse transcriptase, and nuclease-free water, until the final volume was $20 \mu \mathrm{L}$. The mixture was then incubated using $\mathrm{T}^{100^{\mathrm{TM}}}$ Thermal Cycler (Bio-Rad) at $25^{\circ} \mathrm{C}$ for 10 minutes (primers annealing), $42^{\circ} \mathrm{C}$ for 15 minutes (reverse transcription), and $85^{\circ} \mathrm{C}$ for 5 minutes (reverse transcriptase inactivation). The resulting cDNA was stored at $-80^{\circ} \mathrm{C}$ for further use.

Real-time PCR was carried out using T100 ${ }^{\mathrm{TM}}$ Thermal Cycler (Bio-Rad) with a total volume of $10 \mu$ containing specific gene primers, $C D N A$, and GoTaq ${ }^{\circledR}$ Green Master Mix (Promega). cDNA products were denatured for 3 minutes at $95^{\circ} \mathrm{C}$, amplified with 34 cycles (with 30 seconds denaturation at $95^{\circ} \mathrm{C}, 30$ seconds annealing at the temperatures shown in Table 1, and 30 seconds extension at $72^{\circ} \mathrm{C}$ ), and 5 minutes final extension at $72^{\circ} \mathrm{C}$. $\beta$-actin was used as a reference for internal standardization. The gene-specific primer sequences used are mentioned in
Table 1 (obtained from Genetika Science Jakarta, Indonesia) based on study conducted by Wang et al. (2008). Relative gene expression analysis was carried out using method conducted by Livak and Schmittgen (2001).

\subsection{Neutral red staining}

The treated larvae whose pigments had been removed were stained with a neutral red of $2.5 \mu \mathrm{g} / \mathrm{mL}$ concentration for 6-8 hours in the dark (Yang et al., 2014). Macrophages and lysosomes coalesced to form large red aggregates, so that they were easy to detect in the Zebrafish larvae whose pigments had been removed. The macrophages migration to the yolk sac was observed under a microscope.

\subsection{Liver histology}

Euthanized larvae were fixed in freshly prepared Bouin's solution at room temperature for 24 hours, dehydrated in alcohol series, embedded in molten paraffin, and sagittally cut at $5 \mu \mathrm{m}$ of width. Larval sections were stained using hematoxylin-eosin (HE).

\section{Results}

\subsection{Chemical analysis}

Propolis sample used in this research was the same as that used in Wibowo et al. (2020). The CG-MS chemical analysis revealed 25 different compounds. Most of these compounds are phenolic compounds with recognized therapeutic properties. The most abundant compound was $\mathrm{m}$-guaiacol (phenol), $14.07 \%$, as mentioned in Wibowo et al. (2020).

\subsection{Expression levels of complement genes}

The highest $\mathrm{C} 3$ expression level was in larvae from the LPS group (as shown in Figure 1.A). This indicates that more C3 is needed by the larvae from the LPS group to

Table 1. Oligonucleotide Primers Sequence.

\begin{tabular}{|c|c|c|c|c|}
\hline Name & & Sequence & $\begin{array}{l}\text { Dissociation temperature of the } \\
\text { primer } / \mathrm{T}_{\mathrm{m}}\left({ }^{\circ} \mathrm{C}\right)\end{array}$ & Accession Number \\
\hline \multirow[t]{2}{*}{$\beta$-actin } & $\mathrm{F}$ & TTCACCACCACAGCCGAAAGA & 56.52 & AF057040 \\
\hline & $\mathrm{R}$ & TACCGCAAGATTCCATACCCA & 55.07 & \\
\hline \multirow[t]{2}{*}{ C3 } & $\mathrm{F}$ & GTATTACTCACCCGATGCCCG & 56.92 & АВ235997.1 \\
\hline & $\mathrm{R}$ & AGATGGGGTTCACAGGCTTTAAT & 55.91 & \\
\hline \multirow[t]{2}{*}{$\mathrm{C} 1 r / \mathrm{s}$} & $\mathrm{F}$ & GAGTTGTGTTTCAGATGGCTTGC & 56.96 & XM684254.2 \\
\hline & $\mathrm{R}$ & CATTGCGATGGTCTTCAGTTCC & 56.12 & \\
\hline \multirow[t]{2}{*}{$B f$} & $\mathrm{~F}$ & GCTGTCCACGGAAAATAAGG & 53.27 & NM_131338 \\
\hline & $\mathrm{R}$ & TCGGTCGCATCTGCCACT & 58.07 & \\
\hline \multirow[t]{2}{*}{ MBL } & $\mathrm{F}$ & GCAGAGCCAGGAGTGAATGTG & 57.57 & AF227738.1 \\
\hline & $\mathrm{R}$ & ACCTTCTCAATCAGGGCAATC & 54.22 & \\
\hline \multirow[t]{2}{*}{ C6 } & $\mathrm{F}$ & ATGACGCTGGCAAGGAAACT & 56.62 & BC057429 \\
\hline & $\mathrm{R}$ & TGTCTGAACCGCAGGGCTC & 58.77 & \\
\hline
\end{tabular}


activate the complement system, so that it can eliminate the LPS. This phenomenon is contrary to the larvae from the LPSIBU and LPSPRO groups which showed a decrease in C3 gene expression because the inflammation can be suppressed by ibuprofen and the Indonesian propolis. Thus, further complement activation is not required. The result is consistent with Georgieva et al. (1997) who suggested that propolis can generate inactivation of the C3 complement, so that further complement activity, including inflammation, can be inhibited.

In larvae from the LPSIBU and LPSPRO groups, there were decrease in the relative gene expression of the $\mathrm{C} 1 \mathrm{r} / \mathrm{s}$ compared to LPS group (see Figure 1.B). This result is in line with the study of Dimov et al. (1992) that propolis can decrease C1 gene expression and Ivanovska et al. (1995) that propolis can inhibit the complement in the classical and alternative pathways. In zebrafish larvae, the adaptive immune system has not been functional yet, so that the activation of the complement system in the classical pathway is still not yet competent. This is in accordance with a research conducted by Wang et al. (2008).

Relative expression level of $B f$ in larvae from the CON group was almost the same as in larvae from the LPS group (see Figure 1.C). Alternative pathway is also activated under normal conditions to maintain tissue homeostasis with very low level of activation (Merle et al., 2015). In the LPSPRO, a decrease in the relative expression level of $\mathrm{Bf}$ was detected. This finding is in accordance with the research conducted by Ivanovska et al. (1995) which shows that propolis can inhibit the complement in the classical and alternative pathways.

The expression levels of $M B L$ in all groups were not significantly different. It indicates that the $M B L$, as a part of the lectin pathway, in $5 \mathrm{dpf}$ larvae was still not competent yet to be activated. The result is in accordance with the study results of Wang et al. (2008) that LPS challenge did not trigger significant change in $M B L$ expression until $17 \mathrm{dpf}$. In addition, treatments using ibuprofen and the Indonesian propolis do not have significant effects on the MBL expression.

Relative expression level of C6 in the LPSPRO group showed a decrease compared to the LPS group (see Figure 2). It indicates that the Indonesian propolis can inhibit the terminal activity of the complement system. Since the expression level of $\mathrm{C} 3$ had been suppressed, the expression of other complements which are involved in the terminal activity, especially $C 6$, which plays a role in the formation of MAC pores and targeted lysis, could be inhibited.

\subsection{Macrophage migration}

In larvae from the CON group, no macrophages migration to the yolk sac was observed (as seen in Figure 3). It was due to the absence of pathogenic molecules (LPS) which can cause inflammatory response, activate macrophages, and attract them to the yolk sac. There was a higher number of macrophages in the LPS group than those in the CON, LPSIBU, and LPSPRO groups.

\subsection{Histological structure of livers}

Based on the observation, the liver histological structures of all groups were considered normal (see Figure 4). The cell nuclei were clearly visible and the hepatocytes were normally arranged. Changes that occur on the hepatocytes by the LPS are only affected by the dose; the higher the dose of LPS, the more the liver is affected (Bates et al., 2007). The LPS given in this study had sublethal doses. Thus, its effects
A. $C 3$

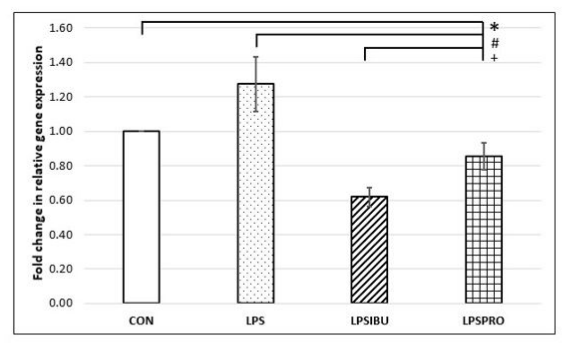

C. $B f$

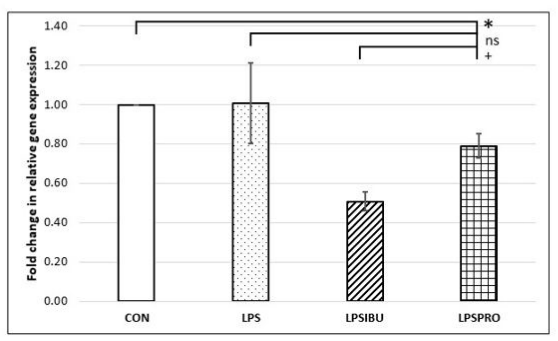

B. $C 1 r / s$

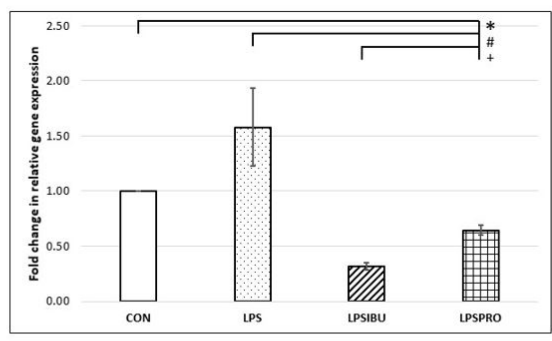

D. $M B L$

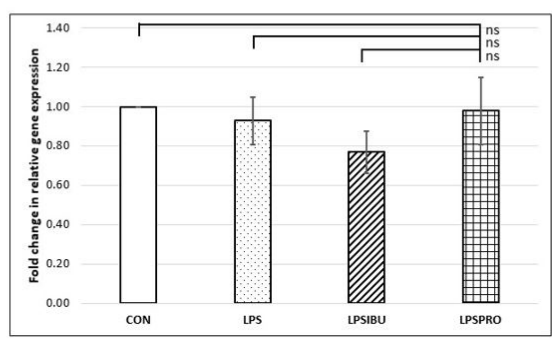

Figure 1. Relative expression levels of $C 3(\mathrm{~A}), \mathrm{C} 1 \mathrm{r} / \mathrm{s}(\mathrm{B})$, and $B f(\mathrm{C})$ in larvae from the LPSIBU and LPSPRO groups were lower than in larvae from the LPS group $(P<0.05)$; relative expression levels of $M B L(D)$ in all group were not different. Data are expressed as mean \pm SEM. Significances marked with ${ }^{*}, \#$, and ${ }^{+}$refer to comparisons to the CON, LPS, and LPSIBU group, respectively. ${ }^{*, \#,+} P<0.05$; ns, not significant. 
on liver structure were not severe. In addition, zebrafish have IAP (intestinal alkaline phosphatase) produced by intestinal epithelium, which could dephosphorylate several serotypes from the LPS, so that the non-toxic products will be produced (Bates et al., 2007).

\section{Discussion}

C3 protein is the central constituent of the complement system since all of the activation pathways converge on the formation of the $\mathrm{C} 3$ convertases (Ricklin and Lambris, 2013). The complement anaphylatoxin resulted can then attract immune cells, including macrophages at the sites of infection, among which is the yolk sac. This is one of the factors that can initiate an increasing number of macrophage migrations to the yolk sac in larvae from the LPS groups. In the LPSIBU and LPSPRO groups, C3 gene expression levels were lower than in larvae from the LPS group. Thus, the number of macrophage migrations

\section{C6}

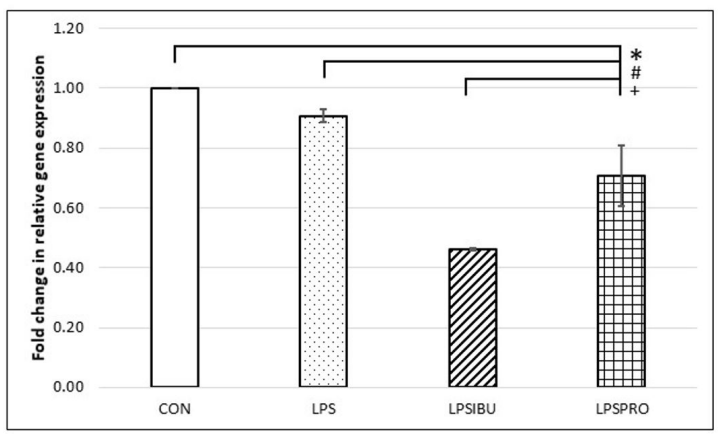

Figure 2. Relative expression level of C6 in larvae from LPSPRO group was lower than from LPS group $(P<0.05)$. Data are expressed as mean \pm SEM. Significances marked with *, ${ }^{*}$, and ${ }^{*}$ refer to comparisons to the CON, LPS, and LPSIBU group, respectively. $*, \#,+P<0.05$. to the yolk sac decreased. This result is consistent with another study conducted by Ansorge et al. (2003) shows that propolis can reduce DNA synthesis in PBMC (peripheral blood mononuclear cells), including monocytes. Propolis can also suppress the production of proinflammatory cytokines (IL-1 $\beta$, IL-2, IL-4, and IL-12) in macrophages.

Macrophages can easily recognize the LPS using TLR4 receptors (Fang et al., 2017). In addition to receptors for recognizing the LPS, macrophages also have other receptors for recognizing complement, which are $\mathrm{C} 3 \mathrm{aR}$ and C5aR receptors for recognizing complement anaphylatoxins C3a and C5a; and CR1, CR3, CR4, and CRIg receptors for recognizing $\mathrm{C} 3 \mathrm{~b}$ as opsonin for pathogens and other foreign agents, so that the phagocytosis can be carried out (Bohlson et al., 2014). Complement anaphylatoxins, $\mathrm{C} 3 \mathrm{a}$ and $\mathrm{C5a}$, are chemoattractants that are capable to recruit immune cells, such as neutrophils, monocytes, and eosinophils, so that they can activate phagocytic cells, induce granular secretion, and increase oxidation formation (Guo and Ward, 2005; Luo et al., 2019).

In larvae from the LPSIBU and LPSPRO groups, there were no changes in the liver histological structure. According to a research conducted Traversa et al. (2003), ibuprofen has low toxic level to the liver because it has a short half-life in plasma, so that it does not form pathological metabolites. The liver treated using the Indonesian propolis showed no changes, as in the other groups. Propolis is known for having various biological activities, among which are hepatoprotective (Miguel and Antunes, 2011). A research conducted by Kismet et al. (2017) shows that propolis has positive effects on the histopathology of NAFLD (non-alcoholic fatty liver disease) because propolis has anti-inflammatory effects. This shows that anti-inflammatory ability is very important in maintaining liver homeostasis from damage possibly caused by inflammation.

Indonesian propolis used in this research contained $14.07 \%$ of m-guaiacol (phenol) and other phenolic compounds (Wibowo et al., 2020). Phenolic compounds are the secondary metabolites which present in plants as a defense mechanism against ultraviolet
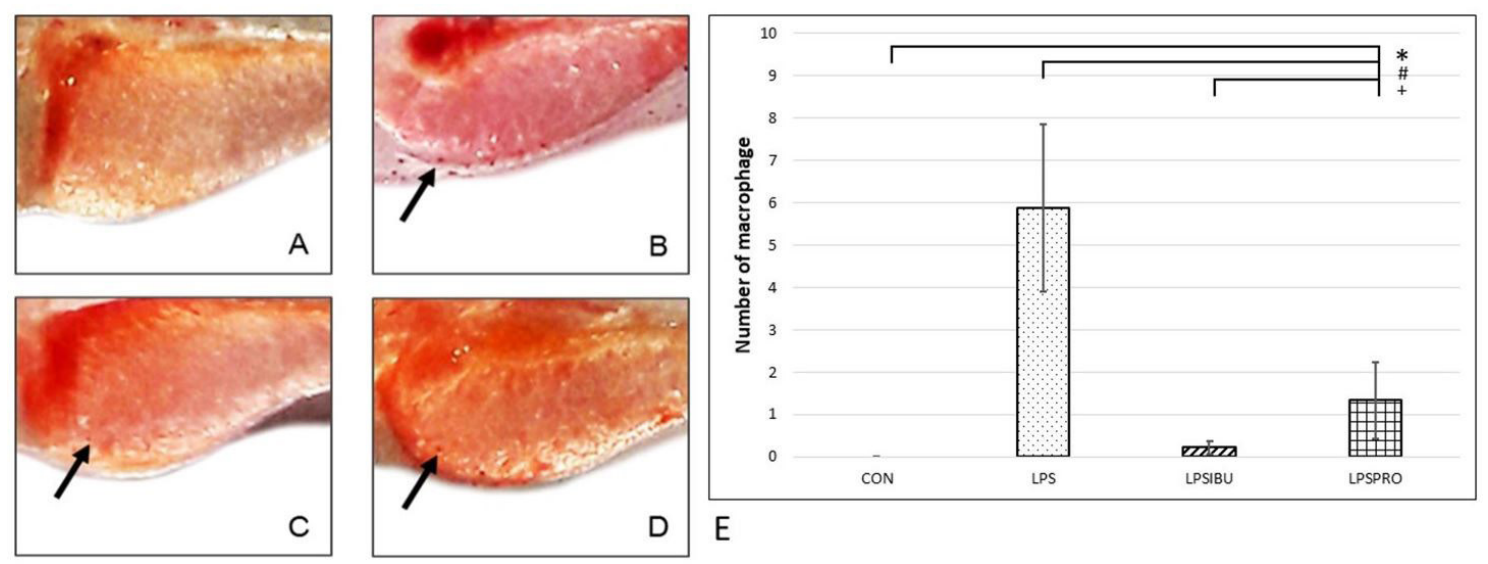

Figure 3. The number of macrophage migration in LPSPRO group was lower than in LPS group $(P<0.05)$. The macrophages were seen as red dots (see arrows): A (CON); B (LPS); C (LPSIBU); D (LPSPRO). E. Quantification result. Data are expressed as mean \pm SEM. Significances marked with *,, , and ${ }^{+}$refer to comparisons to the CON, LPS, and LPSIBU group, respectively. ${ }^{*,+,} P<0.05$. 

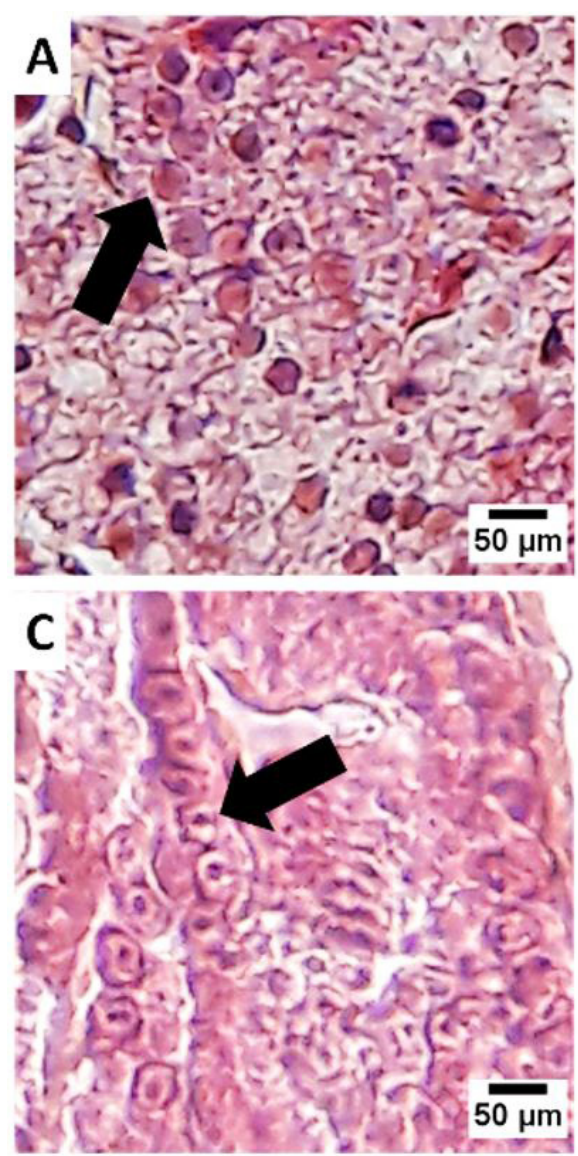
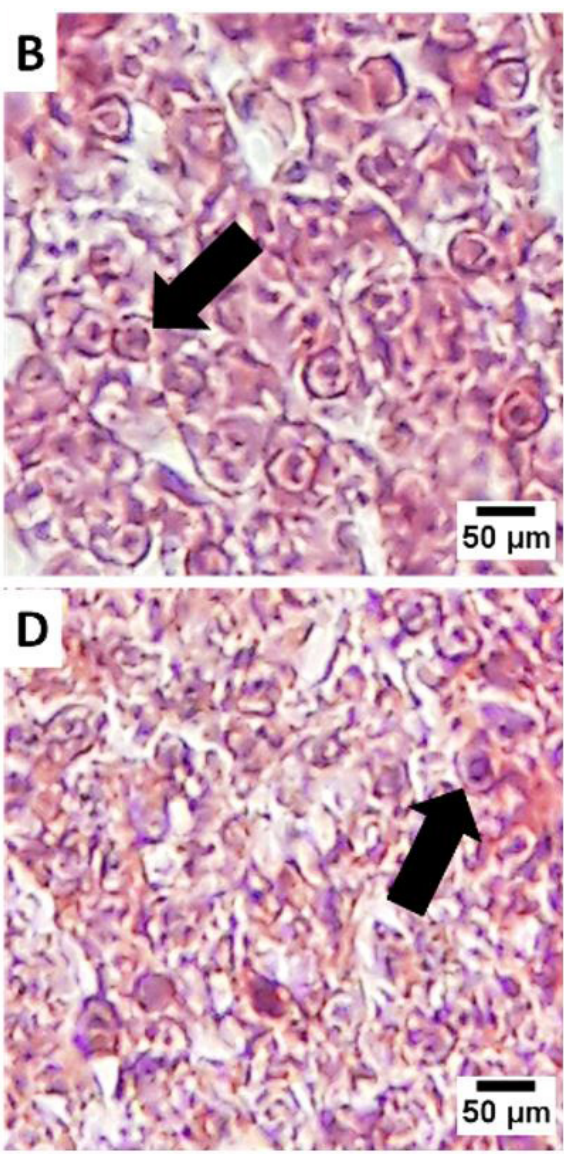

Figure 4. Histological structure of the livers, A (CON); B (LPS); C (LPSIBU); D (LPSPRO). Nuclei are pointed by the arrows.

radiation or pathogens (Pandey and Rizvi, 2009). Those compounds are presumed to exert anti-inflammatory effects (González et al., 2011). A research conducted by Murakami et al. (2007) shows that guaiacol can inhibit COX-2 (cyclooxygenase-2) and NF- $\kappa$ B transcription factors on macrophages which are induced by the LPS. COX-2 is an enzyme that can convert arachidonic acid into prostaglandins (PGE2). Prostaglandins can escalate increased vascular permeability, causing edema, pain, and fever when an inflammatory response occurs (Dennis and Norris, 2015). Ibuprofen also works by inhibiting COX-2, so that it can relieve inflammation, pain, and fever due to the inflammatory response (Bushra and Aslam, 2010). $\mathrm{NF}-\kappa \mathrm{B}$ transcription factors stimulate the formation of proinflammatory cytokines such as TNF- $\alpha$ and IL- $1 \beta$ (Tsubaki et al., 2015).

\section{Conclusion}

In summary, this study shows that the Indonesian propolis reduced the complement genes expression level, the number of macrophage migrations to the yolk, and cause no changes in liver structure. These results suggest that Indonesian propolis has the potential to be used as an alternative to the substitution of NSAIDs (non-steroidal anti-inflammatory drugs). Further research on the mechanism is still necessary.

\section{Acknowledgements}

This research was supported by the Institute for Research and Community Service Institut Teknologi Bandung under the Research, Community Service, and Innovation of Research Groups Program.

\section{References}

ANSORGE, S., REINHOLD, D. and LENDECKEL, U., 2003. Propolis and some of its constituents down-regulate DNA synthesis and inflammatory cytokine production but induce TGF- $\beta 1$ production of human immune cells. Zeitschrift fur Naturforschung. C, Journal of biosciences, vol. 58, no. 7-8, pp. 580-589. http://dx.doi. org/10.1515/znc-2003-7-823. PMid:12939048.

ARANDA, P.S., LAJOIE, D.M. and JORCYK, C.L., 2012. Bleach gel: a simple agarose gel for analyzing RNA quality. Electrophoresis, vol. 33, no. 2, pp. 366-369. http://dx.doi.org/10.1002/elps.201100335. PMid:22222980.

BATES, J.M., AKERLUND, J., MITTGE, E. and GUILLEMIN, K., 2007. Intestinal alkaline phosphatase detoxifies lipopolysaccharide and prevents inflammation in zebrafish in response to the 
gut microbiota. Cell Host \&' Microbe, vol. 2, no. 6, pp. 371-382. http://dx.doi.org/10.1016/j.chom.2007.10.010. PMid:18078689.

BOHLSON, S.S., O'CONNER, S.D., HULSEBUS, H.J., HO, M.M. and FRASER, D.A., 2014. Complement, c1q, and c1q-related molecules regulate macrophage polarization. Frontiers in Immunology, vol. 5, pp. 402. http://dx.doi.org/10.3389/fimmu.2014.00402. PMid:25191325.

BUSHRA, R. and ASLAM, N., 2010. An overview of clinical pharmacology of Ibuprofen. Oman Medical Journal, vol. 25, no. 3, pp. 155-1661. http://dx.doi.org/10.5001/omj.2010.49. PMid:22043330.

CHARCHAFLIEH, J., WEI, J., LABAZE, G., HOU, Y.J., BABARSH, B., STUTZ, H., LEE, H., WORAH, S. and ZHANG, M., 2012. The role of complement system in septic shock. Clinical $\mathcal{E}$ Developmental Immunology, vol. 2012, pp. 407324. http://dx.doi. org/10.1155/2012/407324. PMid:23049598.

DENNIS, E.A. and NORRIS, P.C., 2015. Eicosanoid storm in infection and inflammation. Nature Reviews. Immunology, vol. 15, no. 8 , pp. 511-523. http://dx.doi.org/10.1038/nri3859. PMid:26139350.

DIMOV, V., IVANOVSKA, N., BANKOVA, V. and POPOV, S., 1992. Immunomodulatory action of propolis: IV. Prophylactic activity against gram-negative infections and adjuvant effect of the water-soluble derivative. Vaccine, vol. 10, no. 12, pp. 817-823. http://dx.doi.org/10.1016/0264-410X(92)90043-J. PMid:1455907.

DUNKELBERGER, J.R. and SONG, W.C., 2010. Complement and its role in innate and adaptive immune responses. Cell Research, vol. 20, no. 1, pp. 34-50. http://dx.doi.org/10.1038/cr.2009.139. PMid:20010915.

FANG, W., BI, D., ZHENG, R., CAI, N., XU, H., ZHOU, R., LU, J., WAN, M. and XU, X., 2017. Identification and activation of TLR4mediated signalling pathways by alginate-derived guluronate oligosaccharide in RAW264. 7 macrophages. Scientific Reports, vol. 7, no. 1, pp. 1-13. http://dx.doi.org/10.1038/s41598-01701868-0. PMid:28490734.

FORBES, S.J. and NEWSOME, P.N., 2016. Liver regeneration: mechanisms and models to clinical application. Nature Reviews. Gastroenterology \& Hepatology, vol. 13, no. 8, pp. 473-485. http://dx.doi.org/10.1038/nrgastro.2016.97. PMid:27353402.

GALLI, S.J., BORREGAARD, N. and WYNN, T.A., 2011. Phenotypic and functional plasticity of cells of innate immunity: macrophages, mast cells and neutrophils. Nature Immunology, vol. 12, no. 11, pp. 1035-1044. http://dx.doi.org/10.1038/ni.2109. PMid:22012443.

GEORGIEVA, P., IVANOVSKA, N., BANKOVA, V. and POPOV, S., 1997. Anticomplement activity of lysine complexes of propolis phenolic constituents and their synthetic analogs. Zeitschrift fur Naturforschung. C, Journal of Biosciences, vol. 52, no. 1-2, pp. 60-64. http://dx.doi.org/10.1515/znc-1997-1-211. PMid:9090067.

GONZÁLEZ, R., BALLESTER, I., LÓPEZ-POSADAS, R., SUÁREZ, M.D., ZARZUELO, A., MARTÍNEZ-AUGUSTIN, O. and SÁNCHEZ DE MEDINA, F., 2011. Effects of flavonoids and other polyphenols on inflammation. Critical Reviews in Food Science and Nutrition, vol. 51, no. 4, pp. 331-362. http://dx.doi. org/10.1080/10408390903584094. PMid:21432698.

GUO, R.F. and WARD, P.A., 2005. Role of C5a in inflammatory responses. Annual Review of Immunology, vol. 23, no. 1, pp. 821-852. http:// dx.doi.org/10.1146/annurev.immunol.23.021704.115835. PMid:15771587.

HUANG, S., ZHANG, C.P., WANG, K., LI, G.Q. and HU, F.L., 2014. Recent advances in the chemical composition of propolis. Molecules (Basel, Switzerland), vol. 19, no. 12, pp. 19610-19632. http:// dx.doi.org/10.3390/molecules191219610. PMid:25432012.
IVANOVSKA, N., NEYCHEV, H., STEFANOVA, Z., BANKOVA, V. and POPOV, S., 1995. Influence of cinnamic acid on lymphocyte proliferation, cytokine release and Klebsiella infection in mice. Apidologie, vol. 26, no. 2, pp. 73-81. http://dx.doi.org/10.1051/ apido: 19950201.

JONES, H.S., TROLLOPE, H.T., HUTCHINSON, T.H., PANTER, G.H. and CHIPMAN, J.K., 2012. Metabolism of ibuprofen in zebrafish larvae. Xenobiotica, vol. 42, no. 11, pp. 1069-1075. http://dx.doi.org/10 .3109/00498254.2012.684410. PMid:22594345.

KARLSSON, J., VON HOFSTEN, J. and OLSSON, P.E., 2001. Generating transparent zebrafish: a refined method to improve detection of gene expression during embryonic development. Marine Biotechnology (New York, N.Y.), vol. 3, no. 6, pp. 522-527. http:// dx.doi.org/10.1007/s1012601-0053-4. PMid:14961324.

KIM, G.R., YANG, J.Y., HWANG, K.S., KIM, S.S., CHAE, J.S., KAN, H., AHN, J.H., LEE, W.M., AHN, S.H., LEE, Y.M., BAE, M.A. and SHIN, D.S., 2019. Anti-inflammatory effect of a novel synthetic compound 1-((4-fluorophenyl) thio) isoquinoline in RAW264. 7 macrophages and a zebrafish model. Fish EShellfish Immunology, vol. 87, pp. 395-400. http://dx.doi.org/10.1016/j.fsi.2019.01.030. PMid:30685466.

KISMET, K., OZCAN, C., KURU, S., GENCAY CELEMLI, O., CELEPLI, P., SENES, M., GUCLU, T., SORKUN, K., HUCUMENOGLU, S. and BESLER, T., 2017. Does propolis have any effect on non-alcoholic fatty liver disease? Biomedicine and Pharmacotherapy, vol. 90, pp. 863-871. http://dx.doi.org/10.1016/j.biopha.2017.04.062. PMid:28437890.

LIVAK, K.J. and SCHMITTGEN, T.D., 2001. Analysis of relative gene expression data using real-time quantitative PCR and the 2- $\Delta \Delta C T$ method. Methods (San Diego, Calif.), vol. 25, no. 4, pp. 402-408. http://dx.doi.org/10.1006/meth.2001.1262. PMid:11846609.

LUO, L., LI, X., HU, X., HU, C., TANG, W., DENG, S. and FENG, J., 2019. Anaphylatoxins enhance recruitment of nonclassical monocytes via chemokines produced by pleural mesothelial cells in tuberculous pleural effusion. American Journal of Respiratory Cell and Molecular Biology, vol. 60, no. 4, pp. 454-464. http:// dx.doi.org/10.1165/rcmb.2018-00750C. PMid:30422670.

MARKIEWSKI, M.M. and LAMBRIS, J.D., 2007. The role of complement in inflammatory diseases from behind the scenes into the spotlight. The American Journal of Pathology, vol. 171, no. 3, pp. 715-727. http://dx.doi.org/10.2353/ajpath.2007.070166. PMid:17640961.

MEDZHITOV, R., 2008. Origin and physiological roles of inflammation. Nature, vol. 454, no. 7203, pp. 428-435. http:// dx.doi.org/10.1038/nature07201. PMid:18650913.

MERLE, N.S., NOE, R., HALBWACHS-MECARELLI, L., FREMEAUXBACCHI, V. and ROUMENINA, L.T., 2015. Complement system part II: role in immunity. Frontiers in Immunology, vol. 6, pp. 257. http://dx.doi.org/10.3389/fimmu.2015.00257. PMid:26074922.

MIGUEL, M.G. and ANTUNES, M.D., 2011. Is propolis safe as an alternative medicine? Journal of Pharmacy \& Bioallied Sciences, vol. 3, no. 4, pp. 479-495. http://dx.doi.org/10.4103/09757406.90101. PMid:22219581.

MURAKAMI, Y., HIRATA, A., ITO, S., SHOJI, M., TANAKA, S., YASUI, T., MACHINO, M. and FUJISAWA, S., 2007. Re-evaluation of cyclooxygenase-2-inhibiting activity of vanillin and guaiacol in macrophages stimulated with lipopolysaccharide. Anticancer Research, vol. 27, no. 2, pp. 801-807. PMid:17465205.

NUSSLEIN-VOLHARD, C. and DAHM, R. 2002. Zebrafish, New York: Oxford University Press.

ORYAN, A., ALEMZADEH, E. and MOSHIRI, A., 2018. Potential role of propolis in wound healing: biological properties and 
therapeutic activities. Biomedicine and Pharmacotherapy, vol. 98, pp. 469-483. http://dx.doi.org/10.1016/j.biopha.2017.12.069. PMid:29287194.

PANDEY, K.B. and RIZVI, S.I., 2009. Plant polyphenols as dietary antioxidants in human health and disease. Oxidative Medicine and Cellular Longevity, vol. 2, no. 5, pp. 270-278. http://dx.doi. org/10.4161/oxim.2.5.9498. PMid:20716914.

POLAT, G., UGAN, R.A., CADIRCI, E. and HALICI, Z., 2017. Sepsis and septic shock: current treatment strategies and new approaches. The Eurasian Journal of Medicine, vol. 49, no. 1, pp. 53-58. http:// dx.doi.org/10.5152/eurasianjmed.2017.17062. PMid:28416934.

QIN, X. and GAO, B., 2006. The complement system in liver diseases. Cellular E' Molecular Immunology, vol. 3, no. 5, pp. 333-340. PMid:17092430.

RICKLIN, D. and LAMBRIS, J.D., 2013. Complement in immune and inflammatory disorders: pathophysiological mechanisms. Journal of Immunology (Baltimore, Md.: 1950), vol. 190, no. 8, pp. 3831-3838. http://dx.doi.org/10.4049/jimmunol.1203487. PMid:23564577.

THORGERSEN, E.B., BARRATT-DUE, A., HAUGAA, H., HARBOE, M., PISCHKE, S.E., NILSSON, P.H. and MOLLNES, T.E., 2019. The role of complement in liver injury, regeneration, and transplantation. Hepatology (Baltimore, Md.), vol. 70, no. 2, pp. 725-736. http:// dx.doi.org/10.1002/hep.30508. PMid:30653682.

TRAVERSA, G., BIANCHI, C., DA CAS, R., ABRAHA, I., MENNITIIPPOLITO, F. and VENEGONI, M., 2003. Cohort study of hepatotoxicity associated with nimesulide and other nonsteroidal anti-inflammatory drugs. BMJ (Clinical Research Ed.), vol. 327, no. 7405, pp. 18-22. http://dx.doi.org/10.1136/ bmj.327.7405.18. PMid:12842950.

TSUBAKI, M., TAKEDA, T., KINO, T., ITOH, T., IMANO, M., TANABE, G., MURAOKA, O., SATOU, T. and NISHIDA, S., 2015. Mangiferin suppresses CIA by suppressing the expression of TNF- $\alpha$, IL- 6 , IL-1 $\beta$, and RANKL through inhibiting the activation of NF- $\mathrm{\kappa B}$ and ERK1/2. American Journal of Translational Research, vol. 7, no. 8, pp. 1371-1381. PMid:26396668.

WANG, Z., ZHANG, S. and WANG, G., 2008. Response of complement expression to challenge with lipopolysaccharide in embryos/ larvae of zebrafish Danio rerio: acquisition of immunocompetent complement. Fish EShellfish Immunology, vol. 25, no. 3, pp. 264270. http://dx.doi.org/10.1016/j.fsi.2008.05.010. PMid:18657447.

WEHLING, M., 2014. Non-steroidal anti-inflammatory drug use in chronic pain conditions with special emphasis on the elderly and patients with relevant comorbidities: management and mitigation of risks and adverse effects. European Journal of Clinical Pharmacology, vol. 70, no. 10, pp. 1159-1172. http:// dx.doi.org/10.1007/s00228-014-1734-6. PMid:25163793.

WESTERFIELD, M., 2000. The zebrafish book: a guide for the laboratory use of zebrafish (Danio rerio). 4th ed. Eugene: University of Oregon Press.

WIBOWO, I., NASUTION, F.R., TAUFIK, I., ZAIN, R.S., MARLINDA, N., UTAMI, N., WARDINY, P.Y., PUTRA, R.E., TAN, M.I. and SUMARSONO, S.H., 2020. Anti-inflammatory Activity of Indonesian Propolis in Zebrafish (Danio rerio) Larvae. Journal of Food and Nutrition Research, vol. 8, no. 5, pp. 225-230. http:// dx.doi.org/10.12691/jfnr-8-5-2.

WILKINS, B.J. and PACK, M., 2013. Zebrafish models of human liver development and disease. Comprehensive Physiology, vol. 3, no. 3, pp. 1213-1230. http://dx.doi.org/10.1002/cphy. c120021. PMid:23897685.

YANG, L.L., WANG, G.Q., YANG, L.M., HUANG, Z.B., ZHANG, W.Q. and YU, L.Z., 2014. Endotoxin molecule lipopolysaccharide-induced zebrafish inflammation model: a novel screening method for anti-inflammatory drugs. Molecules (Basel, Switzerland), vol. 19, no. 2, pp. 2390-2409. http://dx.doi.org/10.3390/ molecules 19022390. PMid:24566310.

YÜCEL, G., ZHAO, Z., EL-BATTRAWY, I., LAN, H., LANG, S., LI, X., BULJUBASIC, F., ZIMMERMANN, W.H., CYGANEK, L., UTIKAL, J., RAVENS, U., WIELAND, T., BORGGREFE, M., ZHOU, X.B. and AKIN, I., 2017. Lipopolysaccharides induced inflammatory responses and electrophysiological dysfunctions in human-induced pluripotent stem cell derived cardiomyocytes. Scientific Reports, vol. 7, no. 1, pp. 1-13. http://dx.doi.org/10.1038/s41598-01703147-4. PMid:28592841.

ZHOU, Z., XU, M.J. and GAO, B., 2016. Hepatocytes: a key cell type for innate immunity. Cellular \& Molecular Immunology, vol. 13, no. 3, pp. 301-315. http://dx.doi.org/10.1038/cmi.2015.97. PMid:26685902. 